\title{
Religiosity and Volunteering Intention Among Undergraduate Malaysian Muslim Students
}

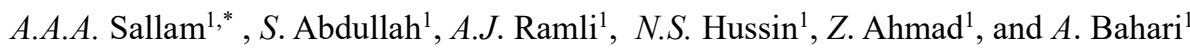 \\ ${ }^{1}$ Universiti Malaysia Perlis, Perlis, Malaysia
}

\begin{abstract}
This paper deals with the question: To what extent do religiosity characteristics, contribute to the influence of volunteering intention among Malaysian Muslim students during disasters? To answer this research question, we focused the students in public universities. The finding concerns found that religiosity increases the likelihood of volunteering intention, implying that religious affiliation of youth increases the likelihood of volunteering. This is in line with previous research, that religious attendance is related positively to volunteering. These results confirm the idea that support of the religious attributes community plays quite a large role in volunteering process. . However, it a bear that volunteering is not only dependent on religious community, but also on individual motivation.
\end{abstract}

\section{Introduction}

Lately, religiosity has emerged as an attractive field of research [1] and there has been increasing interest in the relationships between various aspects of religion [2-3]. Several studies have systematically tried to unveil the underlying dynamics of religiosity in organizational life [4-5]. The influence of religion and spirituality on individual's behaviour has emerged as an area of interest for researchers [6]. In fact, for NPO (non-profit organization), young people are considered a growing and strong volunteer source and essential for the efforts of non-governmental organization (NGO) marketing [7].

In volunteer work, the participation of Australian younger generation is considered lowest in the age group 25-34 [8]. Although there are about 135,000 full-fledged volunteers in Malaysia, the figure only represents less than $1 \%$ of youths aged above 15 [8]. For the explanation and understanding related to youth volunteering, the focus of an individual must be on the factors influencing the motivation or encouraging youth for being a volunteer and positive youth development [9]. A study of youth volunteers of AntiDrug Program findings shows that most of the participants did not know the membership procedures of this Youth Volunteers for the Anti-Drug Program. It is believed that there are some factors that affect students' inactiveness or lack of interest in voluntary activities and in their intention to volunteering. And they should be given the opportunity to participate in various aspects [10]. Also important to develop a student college volunteer [11].

There are very few studies regarding of volunteering intention among college student $[6,11]$.
There is also a lack of research concerning volunteers [12] in developing countries [11], and the relationship between religiosity and volunteers [12]. Recently, the field of testing the influence of religion and spirituality to the psychological behaviour of an individual has been of interest $[6,13-14]$. Despite the researchers scepticism, spirituality and religiosity are considered the influencing factors of emotions, behaviours, cognition, merit of an individual [6, 15-16]. And volunteering behaviour [17]. Moreover, there are many studies of religion and mental health in the context of Christianity context, but studies in Islamic countries are few [18].

Based on the observations, a gap has been found in the literature related to the understanding of the factors influencing the intention of college or university students to volunteering. This study is an attempt to find the literature gap for the investigation of the influencing of religiosity on volunteering intention among Malaysian Muslim students. It will provide for Malaysian organizations, donors and interested ministries the tools and techniques for development of volunteering behaviour among youth, consistent with previous volunteering researches [19-20].

\subsection{Volunteering Intention in Malaysia}

Volunteerism is a method to promote active learning, providing experience which helps in the enhancement of commitment to contribute among citizens, the education experience related to expansion, serving the communities more appropriately. Youth volunteerism is very crucial in developing a community. 
The majority of people joining volunteering activities are retirees. In a study of volunteerism and the development of Malaysian social care system found $4 \%$ had 21-30 years active volunteers and $1 \%$ had 31 40 years active volunteers. Time is considered the barrier for greater in the volunteer practices among younger generation. The issue of younger generation being volunteers is of utmost importance because of their higher level of energy and motivation which can result in good outcome.

\subsection{Purpose of Study}

Although, studies related to volunteering, in previous three decades, have increased [21], little is known about volunteering [22]. Also, about the social and psychological features of volunteers, volunteering motivations, psychological influence [21], and the causal relationship and intentions related to volunteering [19].

The purpose of this study is to examine the relationship between volunteering intention, and how factors of religiosity influence this intention among college students. Several studies have focused on intention or volunteering behaviour of college students [23-24]. A few studies have examined religious preferences and spiritual beliefs among college. However, this study will examine the relationship between volunteering intention and the influence of religiosity specifically among the universities students. There sis notes that, there are very few published studies about religion and health among young persons in Islamic countries [18].

\subsection{Religiosity}

The term religion in this study means the institution serving as a source of knowledge, practice, and beliefs of an individual. From scholarly perspective, religiosity is the level of individuals being religious, and the importance an individual attached to beliefs and practices of religion. Sociologists of religion have struggled with the definition of religion, but agree that religion is more than simply the belief in the supernatural, god, or gods. Religion consists of practices and institutions that have moral purpose. In other words, religion is the organization that provides a set of beliefs, instructions on appropriate practices, and support for individual members, while religiosity is the acceptance of and commitment to those elements provided by religion. It is a collection of organized practices, norms, and values.

Adam Smith in his Theory of Moral Sentiments analysed religiosity from a rational point of view and noted that religiosity acts as a kind of internal moral enforcement mechanism. Individuals characterized as religious are not only those who hold particular religious beliefs but also practice them in day-to-day life [25-26]. For example, religious people pray, attend a place of worship, in some cases observe fasting and engage in socially beneficial actions (e.g., charity and volunteer work), political and economic activity [27]. As directed or encouraged by their religion [5,28]. Many define religiosity as both beliefs and practices relating to an organized religious institution or a specified divine power [29] or to a religious affiliation or to God [30].

\subsection{Religiosity and Volunteering Intention}

Religion is another important predictor of volunteering [8]. Although, there are differences by types of religion and religious denomination, most religions encourage altruism, helping behaviour $[28,31]$ and encourage cooperation between members [32-33] research has shown that religious attendance in particular is related to volunteering behavior [34-36]. It has been shown that the relationship between religiosity and volunteering is mediated by denominational involvement, and is not a direct result of prevailing religious norms and teachings. Crucial are social networks that provide contacts and enhance norm conformity within the group. As well as when investigating influences of individual religious characteristics, it is highly important to control for collective religious characteristics [23] The General Social Survey conducted in 2010 by the Australian Bureau of Statistics shows that volunteering with religious groups was higher among the young (aged 18-24) and older age groups (aged 55-74) and lower in the age group 25-34 [8].

In a study on the role of religiosity for formal and informal volunteering in the Netherlands, found that spirituality increases the likelihood of informal volunteering, implying that openness to other people's needs increases the likelihood of the actual provision of help [23]. They also found in formal volunteering the religious attendance is related positively to formal volunteering, religious as well as secular volunteering [23].

In similarity $[23-24,36]$ found current institutional religious involvement emerged as a positive predictor of the likelihood that men would be involved in volunteer work, as well as of the amount of time that men gave to this kind of work. And Men who are more involved in church life or houses of worship may have a higher probability of being exposed to (or invited to participate in) general volunteer activities. Taniguchi \& Thomas, argue that religious exclusiveness has a significant positive influence on volunteering only in religious areas [38]. Meanwhile, religious inclusiveness is significantly and positively associated with both religious and secular volunteering.

Volunteering for religious organizations shows an interesting pattern in that there are higher odds of participating for those in the range of 18-24 years, controlling for other factors. None of the other life course variables shows a strong relationship with this type of volunteering. Unsurprisingly, an individual's level of religiosity is strongly associated with this kind of volunteering [8]. 


\section{Research Methodology}

\subsection{Participants}

A total of 356 undergraduate students (246 females and 110 males) from two public universities participated in this study. Participants ranged in age from 18-26 years $($ mean $=1.2051)$, and were primarily Malay $(97.2 \%)$ with a minority of others $(2.8 \%)$. Most of the respondents came from Kedah which account for $(11.2 \%)$ and Sarawak with the lower respondent rates of $(0.6 \%)$ of the total students represented. The results showed that respondents consist of $98(27.5 \%)$ first year students, $113(31.7 \%)$ second year students, 90 $(25.3 \%)$ third year students and 55 (14.6\%) fourth year students. Students were recruited from different colleges from two universities Universiti Malaysia Perlis (UNiMAP) and Universiti Utara Malaysia (UUM) and were asked to complete the following selfreport questionnaires. The number of the samples taken from the undergraduate students consisted of 400 respondents which were randomly chosen. 200 sets of questionnaires were distributed, 356 sets were successfully collected back.

\subsection{Measures}

Computer software - Statistical Package for the Social Sciences (SPSS) Version 19.0.1 was used for data analysis. This software was used in this study for data management and analysis. Religiosity towards volunteering intention Scale was developed for the present study under the guidance and supervision of the Universiti Malaysia Perlis. The scale contained 11 items adapted from [23] studies (Table 3.1). Each item was rated by the respondent on a five-point Likert scale ranging from strongly disagree (1) to strongly agree (5) so that scores on the total scale had a possible range of 18 to 26 , with higher scores indicating a more positive religiosity to volunteering intention. Internal reliability was found to be adequate for religiosity (Cronbach's alpha $=0.94$ ) and volunteering intention (Cronbach's alpha $=0.87$ ).

The questionnaire has been developed for measuring religiosity in volunteering intention, a crucial distinction from other measures available which focus on religiosity toward intention to volunteering. Questions include items such as "My religious faith encourages me to volunteer." and "My beliefs about God give me strength to help those who needed assistance." The measure can be found in Table 1 .

Table 1. Measurement of Religiosity.

\begin{tabular}{|c|}
\hline Items \\
\hline My religious faith encourages me to volunteer. \\
\hline $\begin{array}{c}\text { I look to my religion as a source of inspiration to volunteer } \\
\text { in humanity/community services. }\end{array}$ \\
\hline $\begin{array}{c}\text { My religion provides meaning and purpose towards } \\
\text { volunteering activities. }\end{array}$ \\
\hline
\end{tabular}

\begin{tabular}{|c|}
\hline My religion place a high value in helping the needy. \\
\hline My religion influence my intention to volunteer. \\
\hline My religious beliefs make me willing to volunteer. \\
\hline $\begin{array}{c}\text { I feel calm and happy if I involve in humanity/community } \\
\text { service for the sake of my religion. }\end{array}$ \\
\hline I must help the needy in order to please God. \\
\hline $\begin{array}{c}\text { I intent to give money for humanity/community activates } \\
\text { because it is highly encouraged by my religious beliefs. }\end{array}$ \\
\hline $\begin{array}{c}\text { I intend to volunteer to help others because of my religious } \\
\text { beliefs. }\end{array}$ \\
\hline $\begin{array}{c}\text { My beliefs about God give me strength to help those who } \\
\text { needed assistance. }\end{array}$ \\
\hline Source: Adapted from Freiheit et al. (2006); Hernandez
\end{tabular}
(2011)

\section{Results}

The mean for volunteering intention variable which was 4.0314 and religiosity was 4.4941 indicates that the respondents on average agreed with the questions in general. The standard deviation value for volunteering intention is .69127, which is large from mean value and this indicates standard deviation for volunteering intention is less concentrate. Meanwhile, standard deviation religiosity is .54825 . The standardized coefficient is 0.458 for religiosity. The value of R-Square indicates that .210 of the variance in volunteering intention can be predicted from the variables of religiosity. The significant $F$ value of 0.000 which is significant at $\alpha=0.05$. Religiosity value $\mathrm{t}=9.695, \mathrm{p}=0.000$ is significant and the beta value is .587. As the conclusion the religiosity have significant influence on volunteering intention.

\section{Discussion and Conclusion}

In this study, religiosity has a positive and significant effect among Malaysian Muslim students. For religion attributes, it is high correlation and has a significant value. This result is also in line with previous studies that suggested that religious attendance is related positively to volunteering. The elements of religiosity across different religions serve beliefs and practices $[8$ , 23-24, 36, 38]. This result is similar to study by Berger, 2006; and [38] where religiosity has positive relationship with volunteering intention. Therefore, viewed as being a follower of a religious group may be the reason for the increase in the number of invitations for volunteering, and increases the knowledge related to volunteering [39]. In addition, religiosity has many interactions with other factors $[3,23]$. However, there are some limitations, the study focused on limited sample for data collection and the sampling of the study that involved the undergraduate Muslim students of the public universities. Because of this reason, the findings may be applicable only to the university students with higher knowledge and better educational and knowledge background. Thus, the study managed to evaluate students' intention from the public universities students' point of view only. It limits the generalizability of the findings. Therefore, it is 
suggested that future research can be done in larger sample size which include multi-ethnic and other religions that would allow higher response rate for more robust statistical analyses including structural equation modelling.

\section{References}

1. R. A. Emmons, R.F Paloutzian, Annual review of psychology, 54(1), 377-402 (2003)

2. A. F. Shariff, A. K. Willard, T. Andersen, A. Norenzayan, Perso. Soc. Psycho. Rev., 1088868314568811 (2015)

3. S. Vasegh, M. R. Mohammadi, Int. J. Psych. Med., 37(2), 213-227 (2007)

4. M. Benefiel, L. W. Fry, D. Geigle, Psycho. Rel. Spirit., 6(3), 175 (2014)

5. F. Ntalianis, W. Darr, Int. J. Org. Ana, 13(1), 89102 (2005)

6. M. S. Harcrow, Relationships between religiosity, spirituality \& health behaviors among college students (The University of Alabama , 2010)

7. E. Briggs, T. Landry, C. Wood, C., J. Nonp.Public Sect. Market, (2007)

8. E. Gray, S. E. Khoo, A. Reimondos, J. Popu. Res., 29(4), 373-398 (2012)

9. S. Goudeau, Principal Motives of Positive YouthAdult Relationships: A Model for Identifying the Motives of Adult Volunteers and Youth-Adult Relationships in Physical Activity-Based Youth Development Programs (Doctoral dissertation, Emporia State University, 2015)

10. N. A. Suandi, H. A., Suandi, T., Hamzah, S. R. A., Ismail, I. A., Factors Associated with Youth Engagement and Participation in Voluntary Activities in Malaysia (2015)

11. A. Nazilah, I. Rozmi, I. Fauziah, Soc. Sc., 12(9), 139 (2016)

12. M. E. Abreu, R. Laureano, R. V. Da Silva, P. Dionísio, S.S.A. Faridah, The Drivers of Donations Practices in Religious and Secular Organisations, SSRN 2380085 (2013)

13. A. Agorastos, C. Demiralay, C. G. Huber, Psycho. Res. Behav. Man., 7, 93-101 (2014)

14. G. Brewer, S. Robinson, A. Sumra, E. Tatsi, N. Gire, J. Rel. Health, 54(6), 2225-2234 (2015)

15. Khayruzzaman, Int. J. Fin. Bank. Res.. Vol. 2 , No. 1, 2016, pp. 18-23. doi: 10.11648/j.ijfbr.20160201.14 (2016)

16. F. T. Newaz, K. S Fam, R. R. Sharma, J. Fin. Serv. Market., 21(2), 141-152 (2016)

17. E. A. Minton, L. R. Kahle, T. S. Jiuan, S. K. Tambyah, J. Sci. St. Rel., 55(2), 365-383 (2016)

18. S. Vasegh, M. R. Mohammadi, Int. J. Psych. Med., 37(2), 213-227 (2007)

19. J. P. Hill, K. R. den Dulk, J. Sci. St. Rel., 52(1), 179-197 (2013)
20. R. T. DeAngelis, G. A. Acevedo, X. Xu, Rel., 7(6), 74 (2016)

21. N. Morrow-Howell, Psycho. Sc. Soc. Sc. , 65(4), 461-469 (2010)

22. M. E. de Abreu, R. M. S. Laureano, S. F. Syed Alwi, R. V. da Silva, P. Dionísio, Managing Volunteerism Behaviour: The Drivers Of Donations Practices In Religious And Secular Organisations (2015)

23. M. Van Tienen, P. Scheepers, J. Reitsma, H. Schilderman, International J. Volun. Nonp. Org., 22(3), 365-389 (2011)

24. R. D. Putnam, D. E. Campbell, S. R. Garrett, S. R., Simon and Schuster (2012)

25. E. Olson, P. Hopkins, R. Pain, G. Vincett, Ann. Assc. A. Geo., 103(6), 1421-1436 (2013)

26. P. Hopkins, E. Olson, M. Baillie Smith, N. Laurie, Transactions of the Institute of British Geographers, 40(3), 387-398 (2015)

27. P. Cloke, J. May, S. Johnsen, Swept up lives: reenvisioning the homeless city, (John Wiley \& Sons, 2011)

28. N. Krause, Assessing the Religious Roots of Volunteer Work in Middle and Late Life. Research on aging, 37(5), 439-463 (2015)

29. K. I. Pargament, H. A. Raiya, Psyke Logos, 28(2), 25 (2007)

30. E. Dingemans, E. Ingen, Does Religion Breed Trust? A Cross-National (2015)

31. K. M. Loewenthal, Psychology and Charity (2015)

32. K. Coe, C. Keller, J. R. Walker, J. R., J. Rel. Health, 54(1), 46-60 (2015)

33. H. J. Oh, S. J. Lee, K. S. Moon, K. Hong, S. W. Kim, S. W., H. P. Kang, J. Christ. Edu. Info. Techno., 28 (2015)

34. P. Vermeer, P. Scheepers, M. te Grotenhuis, M, VOLUNTAS: International Journal of Voluntary and Nonprofit Organizations, 27(3), 1361-1384 (2016)

35. Y. I. Kim, S. J. Jang, Nonprofit and Voluntary Sector Quarterly, 0899764016655619 (2016)

36. L. Hustinx, R. Van Rossem, F. Handy, R. A. Cnaan, Religion and volunteering: complex, contested and ambiguous relationships (2015)

37. J. S. Mattis, W. P. Beckham, B. A. Saunders, J. E. Williams, V. Myers, D. Knight, C. Dixon, J. Adult Dev., 11(4), 261-272 (2004)

38. H. Taniguchi, L. D. Thomas, VOLUNTAS International Journal of Voluntary and Nonprofit Organizations, (2), 335-355 (2011)

39. I. E. Berger, International Journal of Voluntary and Nonprofit Organizations, 17(2), 110-127 (2006) 